\title{
Multivariate analysis of defensive phase in football: Identification of successful behavior patterns of 2014 Brazil FIFA World Cup
}

\author{
CLAUDIO ALBERTO CASAL-SANJURJO ${ }^{1}$ - MIGUEL ÁNGEL ANDUJAR² ${ }^{2}$ ANTONIO ARDÁ2, RUBÉN \\ MANEIRO ${ }^{3}$, ANTONIO RIAL ${ }^{4}$, JOSÉ LUIS LOSADA ${ }^{5}$ \\ ${ }^{1}$ Department of Science of Physical Activity and Sport, Catholic University of Valencia "San Vicente Mártir", Valencia, \\ Spain \\ ${ }^{2}$ Department of Physical and Sport Education, University of A Coruña, A Coruña, Spain \\ ${ }^{3}$ Department of Science of Physical Activity and Sport, Pontifical University of Salamanca, Spain \\ ${ }^{4}$ Department of Social, Basic Psychology and Methodology, University of Santiago of Compostela, Santiago de \\ Compostela, Spain \\ ${ }^{5}$ Department of Methodology of Behavioral Sciences, University of Barcelona, Barcelona, Spain
}

\begin{abstract}
The aim of this study was to identify variables associated with direct recovery of the ball during defensive transitions in elite soccer and to propose a model with certain guarantees of success based on a multivariate analysis in which binary logistic regression was used to explore interaction between variables. 1,722 defensive transitions were analysed in the final stages of the FIFA World Cup 2014 in Brazil and investigated the following variables: duration of defensive transition; possession loss zone; position of players at the start and end of the defensive transitions, defensive organization, general defensive approach, period of the match, position of defence line, zone in which the offensive transition ends, match status, and outcome of the defensive transition. The variables found to significantly associated with ball recovery were the area of the pitch in which the ball is lost prior to the transition $(p<.05)$, the duration of the transition $(p<.01)$, the position of the defence lines $(p<.01)$, the zone in which the transition ends $(p<.001)$ and end spatial interaction configuration $(p<.001)$. The model that provided the best guarantees of recovering possession was characterized by a defensive transition lasting 15 seconds or less that ends in the holding midfield with the attacking team under pressure.
\end{abstract}

Keywords: Elite football; Match analysis; Observational methodology; Defensive transitions; Logistic regression.

Cite this article as:

Casal-Sanjurjo, C.A., Andujar, M.A., Arda, A., Maneiro, R., Rial, A., \& Losada, J.L. (2021). Multivariate analysis of defensive phase in football: Identification of successful behavior patterns of 2014 Brazil FIFA World Cup. Journal of Human Sport and Exercise, 16(3), 503-516. https://doi.org/10.14198/jhse.2021.163.03

Corresponding author. Department of Science of Physical Activity and Sport, Catholic University of Valencia "San Vicente Mártir", Valencia, Spain. https://orcid.org/0000-0001-9458-6345

E-mail: ca.casal@ucv.es

Submitted for publication January 22, 2020.

Accepted for publication March 10, 2020.

Published July 01, 2021 (in press April 24, 2020).

JOURNAL OF HUMAN SPORT \& EXERCISE ISSN 1988-5202

(C) Faculty of Education. University of Alicante.

doi:10.14198/jhse.2021.163.03 


\section{INTRODUCTION}

Analysis of performance indicators in football is essential in order to better understand how teams play, identify key determinants of success, prepare for future matches, and optimize training sessions. The importance of these indicators is being increasingly recognized, as evidenced by the growing number of studies in this area in recent years (Hughes \& Franks, 2005), (Lago, 2009). Studies of performance in football, however, need to take into account the fact that football is a complex, multifaceted, and particularly unpredictable sport (Chistopher Carling, Wright, Nelson, \& Bradley, 2014) due to its intricate, dynamic system of play (Balague, Torrents, Hristoski, Davids, \& Araujo, 2013; Gréhaigne, 2001; Lames, 1998; Lames \& MacGarry, 2007; MacGarry, Anderson, Wallace, Hughes, \& Franks, 2002; Sampaio \& Maçãs, 2012). Consideration needs to be given to multiple variables that can potentially influence performance and the context of play (Sampaio \& Leite, 2013), such as situational variables, match location (Lago-Peñas \& LagoBallesteros, 2011), the quality of the rival team (Taylor, Mellalieu, James, \& Shearer, 2008), and match status (Lago, 2009). All these variables can influence a team's style of play. Other variables that should be taken into account are the type of competition being played and the phase (e.g., qualifying round or final) (Lago, 2007), interaction between players on both teams (Bloomfield, Polman, \& O'Donoghue, 2005; Harris \& Reilly, 1988; Lames \& MacGarry, 2007; Tenga, Holme, Ronglan, \& Bahr, 2010), and the area of the pitch where the behaviour being analysed occurs (Fradua et al., 2012). Additionally, as these variables interact, they must be studied as they occur during the match and not in isolation (Chistopher Carling et al., 2014).

It has become increasingly clear over the years that studies of performance in football must seek not merely to describe individual and group behaviours but to identify tactical behavioural patterns (James, Mellalieu, \& Hollely, 2002) that help to predict and explain performance (Gréhaigne \& Mahut, 2001). Considerable efforts have been made in this direction in recent years (Ardá, Maneiro, Rial, Losada, \& Casal, 2014; Casal, 2011a; Casal, Losada, \& Ardá, 2015a; Casal, Maneiro, Ardá, Losada, \& Rial, 2014; Lago-Peñas \& Lago-Ballesteros, 2011; Lago-Peñas, Lago-Ballesteros, Dellal, \& Gómez, 2010; Lago-Peñas, Rey, Lago-Ballesteros, Casáis, \& Domínguez, 2011; Tenga et al., 2010). Studies of this type need to use multidimensional, qualitative data rather than unidimensional, quantitative data (Gréhaigne, Mahut, \& Fernández, 2001; Hughes \& Bartlett, 2008; Suzuki \& Nishijima, 2004) if they are to provide more faithful accounts of play (Tenga et al., 2010), predict individual and group tactics performance, and identify the strategies that work best. An allencompassing perspective is needed so that results can be generalized and systematically applied.

Considering the above requirements, the present study was designed to identify factors that influence direct recovery of the ball in elite football and to build a model for predicting successful outcomes. Our findings will show how teams behave in defensive transitions and could provide useful information for football professionals seeking to improve performance in this area.

\section{METHOD}

\section{Participants}

To control some of the situational variables that can potentially affect tactical and strategic team behaviour, such as quality or level of opposing teams and the match location (Carling, Williams, \& Reilly, 2005; Kormelink \& Seeverens, 1999), we analysed 1,722 defensive transitions from the matches played in the FIFA World Cup in Brazil, 2014 (eighth-finals, quarter-finals, semi-finals, and finals). The stage group matches weren't included in the studio because it can happen that some team, in some match, prefer draw than win the match, and this circumstance can influence their normal performance. The period analysed started when the team being observed lost possession of the ball and ended when the other team completed its attack. Only 
defensive transitions that started and ended directly, i.e., without interruptions of play (Barreira, Garganta, Guimaraes, Machado, \& Anguera, 2013) or intervention by the goalkeeper, were recorded and analysed. The study was based on an analysis of publicly available archived match reports and used no experimental data or information that involved human subjects.

\section{Variables}

Ten performance indicators were analysed (Table 1), the majority of which have been used in similar studies (Barreira et al., 2013; Casal, 2011a,b; Casal, Losada, \& Ardá, 2015; Castellano, 2000; Lago-Peñas \& Dellal, 2010; Lames \& MacGarry, 2007; Martins, 2010; Perea, 2008; Mckenzie \& Cushion, 2012; Sampaio \& Leite, 2013; Tenga et al., 2010; Vogelbein, Noops, \& Hökelmann, 2014). The response variable was binary and concerned the outcome of the defensive transition, i.e., success (direct recovery of the ball without intervention of the goalkeeper) or failure, and the explanatory variables were the ten performance indicators analysed.

Table 1. Study criteria and categories.

\begin{tabular}{|c|c|}
\hline Criteria & Categories \\
\hline \multirow{3}{*}{ Duration of defensive transition (DJ) } & DJ $1(0-1 \mathrm{~s})$ \\
\hline & DJ $2(16-30 s)$ \\
\hline & DJ $3(>30 s)$ \\
\hline \multirow{5}{*}{ Possession loss zone (ZP) } & Defensive zone (DF) \\
\hline & Defensive midfield (MD) \\
\hline & Central zone (CE) \\
\hline & Offensive midfield (MOF) \\
\hline & Offensive zone (OF) \\
\hline \multirow{11}{*}{ Start spatial interaction configuration (CEII) } & $\begin{array}{l}\text { Attacking line recovers ball in front of goalkeeper of team } \\
\text { being observed (PA) }\end{array}$ \\
\hline & $\begin{array}{l}\text { Attacking line recovers ball in front of rear line of team being } \\
\text { observed (RA) }\end{array}$ \\
\hline & $\begin{array}{l}\text { Rear line recovers ball in front of middle line of team being } \\
\text { observed (MR) }\end{array}$ \\
\hline & $\begin{array}{l}\text { Attacking line recovers ball in front of middle line of team } \\
\text { being observed (MA) }\end{array}$ \\
\hline & $\begin{array}{l}\text { Middle line recovers ball in front of middle line of team being } \\
\text { observed (MM) }\end{array}$ \\
\hline & $\begin{array}{l}\text { Middle line recovers ball in front of rear line of team being } \\
\text { observed (RM) }\end{array}$ \\
\hline & $\begin{array}{l}\text { Goalkeeper recovers ball in front of attacking line of team } \\
\text { being observed (ARP) }\end{array}$ \\
\hline & $\begin{array}{l}\text { Rear line recovers ball in front of attacking line of team being } \\
\text { observed (AR) }\end{array}$ \\
\hline & $\begin{array}{l}\text { Middle line recovers ball in front of attacking line of team } \\
\text { being observed (AM) }\end{array}$ \\
\hline & $\begin{array}{l}\text { Attacking line recovers ball in front of attacking line of team } \\
\text { being observed (AA) }\end{array}$ \\
\hline & $\begin{array}{l}\text { Goalkeeper recovers ball in front of attacking line of team } \\
\text { being observed }(A \varnothing)\end{array}$ \\
\hline \multirow{2}{*}{ Defensive organization of team being observed (ORD) } & Organized defence \\
\hline & Circumstantial defence \\
\hline General defensive approach (PTGD) & $\begin{array}{l}\text { Expectant } \\
\text { Persistent }\end{array}$ \\
\hline
\end{tabular}




\begin{tabular}{|c|c|}
\hline Period of match $(\mathrm{T})$ & $\begin{array}{l}\text { Minute } 1-15 \\
\text { Minute } 16-30 \\
\text { Minute } 31 \text { to end of first half } \\
\text { Start of second half to minute } 6 \\
61-75 \\
\text { Minute } 76 \text { to end of second half } \\
\text { Start of extra time to end of first half of extra time } \\
\text { Start of second half of extra time to end of extra time }\end{array}$ \\
\hline Position of defence lines (PS) & $\begin{array}{l}\text { Deep } \\
\text { Middle } \\
\text { High }\end{array}$ \\
\hline End of attack zone (ZF) & $\begin{array}{l}\text { Defensive zone (FDF) } \\
\text { Defensive midfield (FMD) } \\
\text { Central zone (FCE) } \\
\text { Offensive midfield (FMO) } \\
\text { Offensive zone (FOF) }\end{array}$ \\
\hline End spatial interaction configuration (CEIF) & $\begin{array}{l}\text { Rear line of team being observed ends defensive transition in } \\
\text { front of attacking line of opposing team (FRA) } \\
\text { Rear line ends defensive transition in front of middle line of } \\
\text { opposing team (FRM) } \\
\text { Middle line ends defensive transition in front of attacking line } \\
\text { of opposing team (FMA) } \\
\text { Middle line ends defensive transition in front of middle line of } \\
\text { opposing team(FMM) } \\
\text { Middle line ends defensive transition in front of rear line of } \\
\text { opposing team (FMR) } \\
\text { Front line ends defensive transition in front of rear line of } \\
\text { opposing team (FAR) } \\
\text { Attacking line ends defensive transition in front of middle line } \\
\text { of opposing team (FAM) } \\
\text { Attacking line ends defensive transition in front of goalkeeper } \\
\text { of opposing team (FAØ) } \\
\text { Goalkeeper ends defensive transition in front of attacking line } \\
\text { of opposing team (FPA) } \\
\text { Goalkeeper ends defensive transition in front of rear line of } \\
\text { team being observed and attacking line of opposing team } \\
\text { (FPRA) }\end{array}$ \\
\hline Match status (RP) & $\begin{array}{l}\text { Winning } \\
\text { Drawing } \\
\text { Losing }\end{array}$ \\
\hline Outcome of defensive transition (RJ) & $\begin{array}{l}\text { Success } \\
\text { Unsuccessful }\end{array}$ \\
\hline
\end{tabular}

\section{Procedure}

The binary logistic regression module in IBM SPSS Statistics v.21 (SPSS Inc., Chicago IL) was used for data analysis. The data were recorded by four observers, each trained in the use of the observation instrument, following the protocols described by (Losada \& Manolov, 2014). To check the progress made during training, a set of data recorded at different moments by each observer was analysed to study intraobserver reliability, with a minimum agreement level of $80 \%$ established (Remmert, 2003). 
To confirm the quality of the data, inter-observer agreement was analysed using the kappa statistic for each category (Table 2 ). The mean kappa value was .887, which corresponds to very good agreement according to the criteria of (Fleiss, Levin, \& Paik, 2003).

Table 2. Kappa values for each category.

\begin{tabular}{lc}
\hline Category & $\mathbf{k}$ \\
\hline Duration of defensive transition & 1 \\
Possession loss zone & .820 \\
Start spatial interaction configuration & .247 \\
Defensive organization & 1 \\
General defensive approach & .812 \\
Position of defence lines & 1 \\
Zone in which defensive transition ends & .881 \\
End spatial interaction configuration & 1 \\
Period of match & 1 \\
Match status & 1 \\
\hline
\end{tabular}

\section{Statistical Analysis}

The level of significance for each performance indicator was set at $5 \%$ as usual in comparable scientific studies (Taylor, Mellalieu, \& James, 2005). In accordance with the objectives of our study, two complementary analyses were performed: a comparative or bivariate analysis and a predictive or multivariate analysis. The bivariate analysis used contingency tables (with chi-square and association measures) to identify variables that were significantly and independently associated with the success of defensive transitions (direct recovery of the ball), while multivariate binary logistic regression analysis was used to predict the effectiveness or success of these transitions according to several characteristics.

\section{RESULTS}

\section{Bivariate analysis}

Contingency tables were constructed to identify statistically significant variables and examine the degree of association between the study variables and direct recovery of the ball during defensive transitions using chisquare tests with calculation of contingency coefficients.

As can be seen in Table 3, five of the variables were significantly associated with successful ball recovery: duration of the defensive transition $\left(X^{2}=10.49 ; p<.01\right)$, the zone in which the team being observed lost the ball $\left(X^{2}=13.13 ; p<.05\right)$, position of the defence lines $\left(X^{2}=9.36 ; p<.01\right)$, the zone in which the transition ended $\left(X^{2}=62.04 ; p<.001\right)$ and end spatial interaction configuration $\left(X^{2}=71.38 ; p<.001\right)$.

Transitions lasting 15 seconds or less were the most effective, with a ball recovery rate of $46.2 \%$. The ball loss zone associated with the greatest likelihood of subsequently recovering possession (46.1\%) was the offensive midfield. The data show that the chances of recovering the ball increase the further away the team is from the goal it is defending. The zones of the pitch in which the defensive transitions ended associated with the highest rates of ball recovery were the holding midfield $(55.7 \%)$ and the defensive midfield $(50.7 \%)$.Specifically, almost $56 \%$ of defensive transitions ending in the holding midfield ended with recovery of the ball. 
Positioning of defence lines high in the pitch was associated with a $45.3 \%$ chance of recovering possession, indicating that pressurizing the attacking team increases the chances of success. Finally, the best end spatial interaction configuration was a rear defence line positioned in front of the middle line of the attacking team (FRM) (successful ball recovery in $76.5 \%$ of cases).

Table 3. Outcome of defensive transitions by study variables.

\begin{tabular}{|c|c|c|c|c|c|c|}
\hline Criteria & & Success & $\begin{array}{c}\text { Un- } \\
\text { successful }\end{array}$ & $x^{2}$ & Sig. & $\begin{array}{c}\text { Contingency } \\
\text { coefficient }\end{array}$ \\
\hline \multirow{3}{*}{$\begin{array}{l}\text { Duration of defensive } \\
\text { transition (DJ) }\end{array}$} & DJ1 (1s - 15s) & $46.2 \%$ & $53.8 \%$ & \multirow{3}{*}{10.49} & \multirow{3}{*}{$<.01$} & \multirow[t]{3}{*}{.11} \\
\hline & DJ2 (16s - 30s) & $39.7 \%$ & $60.3 \%$ & & & \\
\hline & DJ3 (> 30s) & $28.0 \%$ & $72.0 \%$ & & & \\
\hline \multirow{5}{*}{$\begin{array}{l}\text { Possession loss zone } \\
(\mathrm{ZP})\end{array}$} & Defensive zone & $25.0 \%$ & $75.0 \%$ & \multirow{5}{*}{13.13} & \multirow{5}{*}{$<.05$} & \multirow{5}{*}{.13} \\
\hline & Defensive midfield & $22.2 \%$ & $77.8 \%$ & & & \\
\hline & Central zone & $42.8 \%$ & $57.2 \%$ & & & \\
\hline & Offensive midfield & $46.1 \%$ & $53.9 \%$ & & & \\
\hline & Offensive zone & $43.3 \%$ & $56.7 \%$ & & & \\
\hline \multirow{11}{*}{$\begin{array}{l}\text { Start spatial interaction } \\
\text { configuration (CEII) }\end{array}$} & PA & $0.0 \%$ & $62.5 \%$ & \multirow{11}{*}{4.43} & \multirow{11}{*}{.921} & \multirow{11}{*}{---} \\
\hline & RA & $32.1 \%$ & $56.3 \%$ & & & \\
\hline & RM & $40.0 \%$ & $47.4 \%$ & & & \\
\hline & $\mathrm{MA}$ & $37.5 \%$ & $60.6 \%$ & & & \\
\hline & MM & $43.7 \%$ & $58.1 \%$ & & & \\
\hline & MR & $52.6 \%$ & $50.0 \%$ & & & \\
\hline & ARP & $39.4 \%$ & $50.0 \%$ & & & \\
\hline & AR & $41.9 \%$ & $54.5 \%$ & & & \\
\hline & AM & $50.0 \%$ & $62.5 \%$ & & & \\
\hline & AA & $50.0 \%$ & $56.3 \%$ & & & \\
\hline & $\mathrm{A} \varnothing$ & $45.5 \%$ & $47.4 \%$ & & & \\
\hline \multirow{2}{*}{$\begin{array}{l}\text { Defensive organization of } \\
\text { team being observed } \\
(\text { ORD) }\end{array}$} & Organized defence & $42.9 \%$ & $57.1 \%$ & \multirow[b]{2}{*}{0.25} & \multirow[b]{2}{*}{.61} & \multirow[b]{2}{*}{---} \\
\hline & Circumstantial defence & $30.0 \%$ & $70.0 \%$ & & & \\
\hline \multirow{2}{*}{$\begin{array}{l}\text { General defensive } \\
\text { approach (PTGD) }\end{array}$} & Expectant & $40.0 \%$ & $60.0 \%$ & \multirow{2}{*}{1.67} & \multirow{2}{*}{.19} & \\
\hline & Persistent & $44.8 \%$ & $55.2 \%$ & & & -- \\
\hline Period of match (T) & $\mathrm{T}-15: 0-15 \mathrm{~min}$ & $48.9 \%$ & $51.1 \%$ & & & \\
\hline & $\mathrm{T}-30: 16-30 \mathrm{~min}$ & $36.8 \%$ & $63.2 \%$ & & & \\
\hline & $T-45: 31-45 \min$ & $41.9 \%$ & $58.1 \%$ & & & \\
\hline & $\mathrm{T}-60: 46-60 \mathrm{~min}$ & $50.0 \%$ & $50.0 \%$ & & & -- \\
\hline & $\mathrm{T}-75: 61-75 \mathrm{~min}$ & $43.0 \%$ & $57.0 \%$ & 11.55 & .11 & \\
\hline & $\mathrm{T}-90: 76-90 \mathrm{~min}$ & $38.9 \%$ & $61.1 \%$ & & & \\
\hline & $\mathrm{T}-105$ : First half of extra time & $25.9 \%$ & $74.1 \%$ & & & \\
\hline & T-120: Second half of extra time & $36.4 \%$ & $63.6 \%$ & & & \\
\hline Position of defence lines & Deep & $23.1 \%$ & $76.9 \%$ & & & \\
\hline (PS) & Middle & $37.8 \%$ & $62.2 \%$ & 9.36 & $<.01$ & .11 \\
\hline & High & $45.3 \%$ & $54.7 \%$ & & & \\
\hline End of defensive & Defensive zone & $25.2 \%$ & $74.8 \%$ & & & \\
\hline transition zone (ZF) & Defensive midfield & $50.7 \%$ & $49.3 \%$ & & & .27 \\
\hline & Central zone & $55.7 \%$ & $44.3 \%$ & 62.04 & $<.001$ & \\
\hline & Offensive midfield & $46.2 \%$ & $53.8 \%$ & & & \\
\hline & Offensive zone & $4.5 \%$ & $95.5 \%$ & & & \\
\hline End spatial interaction & FPA & $0.0 \%$ & $100.0 \%$ & & & \\
\hline configuration (CEIF) & FPRA & $0.0 \%$ & $100.0 \%$ & & & \\
\hline & FRA & $46.0 \%$ & $54.0 \%$ & & & \\
\hline & FRM & $76.5 \%$ & $23.5 \%$ & & & \\
\hline & FMA & $37.5 \%$ & $62.5 \%$ & & & \\
\hline & FMM & $48.8 \%$ & $51.2 \%$ & 11.38 & $<.001$ & .29 \\
\hline & FMR & $62.5 \%$ & $37.5 \%$ & & & \\
\hline & FAR & $27.3 \%$ & $72.7 \%$ & & & \\
\hline & FAM & $62.5 \%$ & $37.5 \%$ & & & \\
\hline & $\mathrm{FA \varnothing}$ & $16.7 \%$ & $83.3 \%$ & & & \\
\hline Match status (RP) & Winning & $44.9 \%$ & $55.1 \%$ & & & --- \\
\hline & Drawing & $44.1 \%$ & $55.9 \%$ & 3.49 & .17 & \\
\hline & Losing & $35.6 \%$ & $64.4 \%$ & & & \\
\hline
\end{tabular}


The best chances of recovering possession during a defensive transition would appear to determine by loss of the ball in the offensive midfield, a transition lasting 15 seconds or less and ending in the offensive midfield, defence lines positioned high in the pitch, and a rear defence line positioned in front of the middle line of the attacking team at the end of the transition (FRM).

The two variables most closely associated with outcome were the end spatial interaction configuration and the area of the pitch in which the transition ended (contingency coefficients of .29 and .27, respectively).

\section{Logistic regression analysis}

Binary logistic regression analysis was used to build a model to explain and predict the effectiveness of defensive transitions in terms of recovering the ball.

The response variable was success/failure (i.e., recovery or not of possession), while the explanatory variables were the five variables found to be statistically significant in the bivariate analysis.

DEFENSIVE TRANSITION OUTCOME $f_{(x)}=\alpha+\beta_{1}$ (Duration of Transition) $+\beta_{2}$ (Possession Loss Zone) + $\beta_{3}($ Position of Defence Lines $)+\beta_{4}($ Transition End Zone $)+\beta_{5}($ End Spatial Interaction Configuration $)+\varepsilon$

Table 4. Results of logistic regression with original data.

\begin{tabular}{llllll}
\hline Variables & B & S.E. & Wald & Sig. & Exp (B) [Cl] \\
\hline ZF (End zone) & & & 25.14 & $<.001$ & \\
ZF1 (Defensive zone) & 1.65 & 1.07 & 2.36 & .12 & $5.21[.63-42.82]$ \\
ZF2 (Defensive & 2.46 & 1.06 & 5.35 & $<.05$ & $11.71[1.45-94.18]$ \\
midfield) & 2.74 & 1.07 & 6.58 & $<.01$ & $15.41[1.91-124.55]$ \\
ZF3 (Central zone) & 2.55 & 1.07 & 5.74 & $<.05$ & $12.81[1.59-103.23]$ \\
ZF4 (Offensive midfield) & 2.55 & & & & \\
CEIF (End spatial & & & 10.23 & .33 & \\
interaction & & & & & \\
configuration) & & & & & \\
CEIF1 (FPA) & -19.61 & 8124.53 & 0.00 & .99 & $0.00[0.00-]$ \\
CEIF2 (FPRA) & -19.61 & 6133.38 & 0.00 & .99 & $0.00[0.00-]$ \\
CEIF3 (FRA) & 0.99 & 1.11 & 0.76 & .38 & $2.69[0.29-24.76]$ \\
CEIF4 (FRM) & 2.05 & 1.27 & 2.59 & .11 & $7.75[0.64-93.84]$ \\
CEIF5 (FMA) & 0.34 & 1.35 & 0.06 & .80 & $1.40[0.09-19.79]$ \\
CEIF6 (FMM) & 0.69 & 1.14 & 0.37 & .54 & $1.99[0.21-18.71]$ \\
CEIF7 (FMR) & 1.18 & 1.35 & 0.77 & .38 & $3.27[0.23-46.09]$ \\
CEIF8 (FAR) & 0.19 & 1.19 & 0.03 & .87 & $1.22[0.12-12.62]$ \\
CEIF9 (FAM) & 1.18 & 1.35 & 0.77 & .38 & $3.26[0.23-46.09]$ \\
Constant & -3.31 & 1.51 & 4.76 & $<.05$ & 0.04 \\
\hline X2 (sig) & Nagelkerke & Hosmer \& & \multicolumn{3}{l}{$\%$ Correctly Classified } \\
\hline 126.61 (p<.001) & $\mathbf{R}^{2}$ & Lemeshow & \multicolumn{5}{l}{ Transitions } \\
\hline
\end{tabular}

The model was built using stepwise logistic regression with the Wald statistic as the inclusion criterion and the last category of each variable as the reference category. As can be seen in Table 4, the resulting model, based on the equation containing the transition end zone (ZF) variables and the end spatial interaction configuration (CEIF) variables, was statistically significant $\left(X^{2}=126.61 ; p<.001\right)$. However, it was not 
possible to calculate the confidence interval for the odds ratios for CEIF1 (FPA) or CEIF2 (FPRA), which both had extremely high standard errors. The differences between the different categories of this variable were also insignificant.

We therefore decided to perform another analysis, excluding situations that resulted in very few or no recoveries of the ball, namely FAØ (attacking line ending transition in front of the rival's goal), which accounted for barely $0.7 \%$ of cases, and FPA and FPRA (goalkeeper ending transition in front of rival's attacking line and in front of the rear line of his own team and the attacking line of the rival team, respectively). These situations resulted in no recoveries of the ball. In this second analysis, the CEIF variable was divided into just two categories:

a) CEIF1 (pressure defence). This included all situations in which a defence line of the team being observed recovered the ball further up the field than would be expected in a balanced situation (FMR, FRM).

b) CEIF2 (balanced/deep defence). This included situations in which a defence line of the team being observed recovered the ball in front or behind the lines that would be expected (FRA, FMM, FAR, FMA, FAM).

As shown in Table 5, this new model was also statistically significant $\left(\chi^{2}=48.55 ; p<.001\right)$, but it had relatively poor predictive strength $\left(\mathrm{R}^{2}=.086\right)$.

Table 5. Results of the Logistic Regression Analysis Using the Recoded CEIF Variable.

\begin{tabular}{|c|c|c|c|c|c|}
\hline Variables & B & S.E. & Wald & Sig. & $\operatorname{Exp}(B)[I C]$ \\
\hline ZF & & & 21.19 & $<.001$ & \\
\hline ZF1 & 2.30 & 1.04 & 4.86 & $<.05$ & $10.00[1.29-77.35]$ \\
\hline ZF2 & 2.94 & 1.03 & 8.07 & $<.01$ & $19.03[2.49-145.32]$ \\
\hline ZF3 & 3.04 & 1.04 & 8.53 & $<.01$ & $20.91[2.72-160.94]$ \\
\hline ZF4 & 2.58 & 1.05 & 5.98 & $<.05$ & $13.19[1.67-104.21]$ \\
\hline DJ & & & 8.85 & $<.05$ & \\
\hline DJ1 & 0.82 & 0.28 & 8.68 & $<.01$ & $2.27[1.32$ - 3.93$]$ \\
\hline DJ2 & 0.62 & 0.30 & 4.28 & .05 & $1.87[1.03-3.38]$ \\
\hline CEIF1 & 0.92 & 0.46 & 3.99 & $<.05$ & $2.50[1.02-6.16]$ \\
\hline Constant & -3.59 & 1.06 & 11.40 & $<.01$ & 0.03 \\
\hline$x^{2}$ (sig) & $\begin{array}{l}\text { Nagelkerke } \\
\mathrm{R}^{2}\end{array}$ & & $\begin{array}{l}\text { Hosmer \& } \\
\text { Lemeshow }\end{array}$ & & $\begin{array}{l}\text { orrectly Classified } \\
\text { sitions }\end{array}$ \\
\hline $48.55(p<.001)$ & .086 & & $2.14(p=.95)$ & & \\
\hline
\end{tabular}

Three variables were included in the equation: transition end zone (ZF), transition duration (DJ), and end spatial interaction configuration (CEIF). The other variables were statistically insignificant $(p>.05)$ and therefore not contemplated.

For the first variable, transition end zone, the positive signs associated with the logistic coefficients (B) show that all the categories were associated with greater ball recovery than the reference category (offensive zone). The highest odds ratio (OR) was seen in the category ZF3, where it was seen that an attack ending in the holding midfield was associated with 20.91 -fold increased odds of recovering the ball than one ending in the offensive zone. 
The sign associated with transition duration was also positive, indicating that transitions lasting 1 to 15 seconds (DJ1) and 16 to 30 seconds (DJ2) were more effective than those lasting over 30 seconds (reference category). The highest OR was observed for DJ1, indicating that the odds of a transition ending in recovery of possession was 2.27 higher for transitions lasting no more than 15 seconds than for those lasting more than 30 seconds.

The third variable, CEIF1 (pressure defence at the end of a defensive transition) was also associated with a positive coefficient $(B=0.92)$ and an odds ratio of 2.50 , indicating that the odds of a successful outcome are two and a half times higher when the attacking lines of the opposing team are put under pressure.

Once the values of the different variables have been estimated, the predictive equation can be expressed in Logit units to estimate the likelihood of recovering possession based on the best options for each variable, i.e., a defensive transition lasting 15 seconds or less that ends in the holding midfield with the attacking team under pressure.

$$
\text { Logit }(p)=-3.59+3.04(Z F 3)+0.82(D J 1)+0.92(C E I F 1)=0.766
$$

Under these conditions, the likelihood of recovering the ball was $76.6 \%$. The use of logistic regression thus showed that under ideal circumstances, the chances of recovering the ball increased from $42.8 \%$ (percentage of effective transitions recorded in the matches analysed) to $76.6 \%$, which is an almost two-fold increase.

\section{DISCUSSION}

The aim of this study was to identify variables associated with direct recovery of the ball during defensive transitions in elite football and to propose a model with certain guarantees of success, for this 1722 defensive transitions were analysed in the final stages of the FIFA World Cup 2014 in Brazil.

This study identified five variables significantly associated with the outcome of defensive transitions in elite football: the area of the pitch in which the ball is lost prior to the transition, the duration of the transition, the position of the defence lines, the zone in which the transition ends, and the end spatial interaction configuration.

The data show that transitions lasting 15 seconds or less are the most effective in terms of recovering the ball. This finding is consistent with the observation by Casal, Andujar, Losada, Ardá, \& Maneiro (2016) and Vogelbein et al. (2014) that defences actively recover the ball within 0 and 14 seconds, and with results by Casal (2011a) and Casal et al. (2015b), who showed that offensive transitions that start with direct recovery of the ball last for an average of 16 seconds, as would logically the corresponding defensive transitions. The fact that shorter transitions led more frequently to recovery of possession also supports reports by Jones, James, \& Mellalieu (2004); Hughes \& Franks (2005); López (2007); Lago-Ballesteros \& Lago (2010); LagoPeñas \& Dellal (2010); Rees, James, Hughes, \& Taylor (2011); De Oliveira (2012) and Lago-Ballesteros, Lago, Rey, Casáis, \& Domínguez (2012), that teams are more effective in situations marked by long possessions and short defensive transitions.

The zone in which the team lost possession of the ball prior to launching its defence associated with the greatest chances of recovery of the ball was the offensive midfield, indicating that the chances of regaining possession increase the further away the players are from their goal when they lose the ball. These data are similar to the study of Casal et al. (2016) and its explanation may be because the team has more time to 
reorganize its defence and has more players behind the ball that can directly participate in its recovery, and also possibly because the attacking team has to cover longer distances and beat more defenders to reach the goal area.

In our series, defensive transitions ending in the holding and defensive midfield zones resulted in the highest rates of ball recovery. This observation is similar to reports by Casal et al. (2016); Garganta (1997); Tenga et al., (2010); Casal (2011a,b); Lago-Ballesteros, Lago-Peñas, \& Rey (2012); Barreira et al. (2013) and Casal, Andujar, Losada, Ardá, \& Maneiro (2016) that balls are recovered most frequently in the defensive and defensive midfield zones.

The further up the pitch the defence lines are located, the greater the chances of a successful outcome. In other words, putting pressure on the attacking players appears to be a successful strategy for recovering the ball.

In relation to the results of the multivariate analysis we have verified that, if we execute defensive transitions trying to recover possession in the first 15 seconds, pressing the rival team in the central zone of the field, the probabilities of success will be greater than in the rest of situations. These results coincide in part with the model designed by Casal et al. (2016), its most effective model also indicated that the recovery should try to be made in the first 15 seconds of the defensive transition. In this study, we have identified tactics that influence the success of defensive transitions in terms of recovering possession of the ball and built a model to help to optimize performance in these situations. Nevertheless, the poor predictive strength of the model shows that there are other, unknown, factors involved, highlighting the need for further studies. It would also be interesting to use a larger sample and analyse different competitions to improve the generalizability of results. Despite the limitations of our study, we believe that our results could help football coaches to design training sessions aimed at improving performance in this area in match situations.

\section{CONCLUSIONS}

This study had two objectives: to identify performance indicators related to the direct recovery of the ball in elite football and, using these indicators, to build a model for predicting outcomes of defensive transitions and improving performance in this area. Five variables had a significant influence on ball recovery: the area of the pitch in which the ball is lost prior to the transition, the duration of the transition, the position of the defence lines, the zone in which the transition ends, and the end spatial interaction configuration. There was also evidence that the chances of recovering the ball increase when the defending team loses the ball in the offensive midfield, when the defensive transition lasts 15 seconds or less and ends in the holding midfield, when the defence lines are positioned high in the pitch, and when the rear defence line is located in front of the middle line of the attacking team when the transition ends.

Logistic regression analysis based on the above performance indicators showed that the chances of recovering the ball increased by almost 34\% when teams used a defensive transition of no more than 15 seconds and put pressure on the attacking team in the holding midfield.

\section{AUTHOR CONTRIBUTIONS}

M.A.A and A.A conceived, designed the experiments and collected the data; C.A.C performed the experiments, wrote the paper and collected the data; J.L.L analysed the data; R.M contributed materials/analysis tools and collected the data and A.R. critically reviewed the work. 


\section{SUPPORTING AGENCIES}

We gratefully acknowledge the support of Generalitat Valenciana project: Análisis observacional de la acción de juego en el fútbol de élite (Consellería d'Educació, Investigació, Cultura i Esport) during the period: 2017 2019 (GV2017/044). We also acknowledge the support of Universidad Católica de Valencia "San Vicente Mártir" project: Estudios en el deporte de élite desde los Mixed Methods: técnicas de análisis de estudios comparativos, during the period 2018 [Grant UCV2017/230-002].

\section{DISCLOSURE STATEMENT}

The authors declare no conflict of interest.

\section{REFERENCES}

Ardá Suárez, T., Maneiro Dios, R., Rial Boubeta, A., Losada López, J., \& Casal Sanjurjo, C. (2014). Efficiency analysis of corner kicks in the 2010 world cup. Trying to identify the explanatory variables. Revista De Psicologia Del Deporte, 23(1), 165-172. Retrieved from https://www.rpdonline.com/article/view/v23-n1-arda-maneiro-rial-etal

Balague, N., Torrents, C., Hristoski, R., Davids, K., \& Araujo, D. (2013). Overview of complex systems in sport. Journal of Systems Science \& Complexity, 26(1), 4-13. https://doi.org/10.1007/s11424-0132285-0

Barreira, D., Garganta, J., Guimaraes, P., Machado, J. C., \& Anguera, M. T. (2013). Ball recovery patterns as a performance indicator in elite soccer. Journal of Sport Engineered and Technology. https://doi.org/10.1177/1754337113493083

Bloomfield, J. R., Polman, R. C. J., \& O'Donoghue, P. G. (2005). Effects of score-line on intensity of play in midfield and forward players in the FA Premier League. Journal of Sports Sciences, 23, 191-192.

Carling, C., Williams, A. M., \& Reilly, T. (2005). Handbook of soccer match analysis: A systematic approach to improving performance. Abingdon UK: Routledge.

Carling, Chistopher, Wright, C., Nelson, L. J., \& Bradley, P. (2014). Comment on 'Performance analysis in football: A critical review and implications for future research'. Journal of Sports Sciences, 32(1), 2-7. https://doi.org/10.1080/02640414.2013.807352

Casal, C. A. (2011a). Cómo mejorar la fase ofensiva en el fútbol: Las transiciones ofensivas. Alemania: Editorial Académica Española.

Casal, C. A. (2011b). Estudio descriptivo de las transiciones ofensivas en el fútbol. EFDeportes.com, Año 16(159).

Casal, C. A., Andujar, M. A., Losada, J. L., Ardá, T., \& Maneiro, R. (2016). Identification of Defensive Performance Factors in the 2010 FIFA World Cup South Africa. Sports, 4(54). https://doi.org/10.3390/sports4040054

Casal Sanjurjo, C., Losada López, J., \& Ardá Suárez, T. (2015). Estudio de los factores de rendimiento de la fase ofensiva en el fútbol de alto nivel. Revista De Psicologia Del Deporte, 24(1), 103-110. Retrieved from https://www.rpd-online.com/article/view/1392

Casal, C. A., Maneiro, R., Ardá, T., Losada, J. L., \& Rial, A. (2014). Effectiveness of Indirect Free Kicks in Elite Soccer. International Journal of Performance Analysis in Sport, 14, 744-750. https://doi.org/10.1080/24748668.2014.11868755

Casal, C., Andujar, M., Losada, J., Ardá, T., \& Maneiro, R. (2016). Identification of Defensive Performance Factors in the 2010 FIFA World Cup South Africa. Sports, 4(4), 54. https://doi.org/10.3390/sports4040054 
Castellano, J. (2000). Observación y análisis de la acción de juego en el fútbol. Universidad del País Vasco, Vitoria-Gasteiz.

De Oliveira, P. . (2012). A influencia das variáveis situacionais no comportamento posicional de uma equipa profissional de futebol no instante de recuperação da posse da bola. Um estudo de caso. Universidade de Vigo, Pontevedra.

Fleiss, J. L., Levin, B., \& Paik, M. C. (2003). Statistical methods for rates and proportions (3a). Hoboken: John Wiley y Sons.

Fradua, L., Zubillaga, A., Caro, O., Fernández, A., Ruiz-Ruiz, C., \& Tenga, A. (2012). Designing smallsided games for training tactical aspects in soccer: Extrapolating pitch sizes from full-size professional matches, Journal of Sports Sciences, 31:6, 573-581. https://doi.org/10.1080/02640414.2012.746722

Garganta, J. (1997). Modelação táctica do jogo de Futebol. Estudo da organização da fase ofensiva em equipas de alto rendimento. Universidade do Porto.

Gréhaigne, J. (2001). La organización del juego en el fútbol. Barcelona: INDE.

Gréhaigne, J., \& Mahut, B. (2001). Qualitative observation tools to analyse soccer. International Journal of Performance Analysis in Sport, 1(1), 52-61. https://doi.org/10.1080/24748668.2001.11868248

Harris, S., \& Reilly, T. (1988). Space, team work and attacking success in soccer. En Science and Football (In T. Reilly, A. Lees, K. Davids, W. J. Murphy, pp. 322-328). London: E. y F.N.Spon.

Hughes, M., \& Bartlett, R. (2008). What is performance analysis? En The essentials of performance analysis: An introduction (In M.Hughes \& I. Franks, pp. 8-20). London: Routledge.

Hughes, M., \& Franks, I. (2005). Analysis of passing sequences, shots and goals in soccer. Journal of Sports Sciences, 23(5), 509-514. https://doi.org/10.1080/02640410410001716779

James, N., Mellalieu, S. ., \& Hollely, C. (2002). Analysis of strategies in soccer as a function of European and domestic competition. International Journal of Performance Analysis in Sport, s, 85-103. https://doi.org/10.1080/24748668.2002.11868263

Jones, P. D., James, N., \& Mellalieu, S. . (2004). Possession as a performance indicator in soccer. International Journal of Performance Analysis of Sport, 4, 98-102. https://doi.org/10.1080/24748668.2004.11868295

Kormelink, H., \& Seeverens, T. (1999). Match analysis and game preparation. Spring City, PA: Reedswain.

Lago, C. (2007). Are winners different from losers? Performance and chance in the FIFA World Cup Germany 2006. International Journal of Performance Analysis in Sport, 7, 36-47. https://doi.org/10.1080/24748668.2007.11868395

Lago, C. (2009). The influence of match location, quality of opposition, and match status on possession strategies in professional association football. Journal of Sports Sciences, 27(13), 1463-1469. https://doi.org/10.1080/02640410903131681

Lago-Ballesteros, J., \& Lago, C. (2010). Performance in team sports: identifying the keys to success in soccer. Journal of Human Kinetics, 25, 85-95.

Lago-Ballesteros, J., Lago, C., Rey, E., Casáis, L., \& Domínguez, E. (2012). El éxito ofensivo en el fútbol de élite. Influencia de los modelos tácticos empleados y de las variables situacionales. Motricidad. European Journal of Human Movement, 28, 145-170.

Lago-Ballesteros, J., Lago-Peñas, C., \& Rey, E. (2012). The effect of playing tactics and situational variables on achieving scorebox possessions in a professional soccer team. Journal of Sports Sciences, 30, 1455-1461. https://doi.org/10.1080/02640414.2012.712715

Lago-Peñas, C., \& Dellal, A. (2010). Ball Possession Strategies in Elite Soccer According to the Evolution of the Match-Score: the Influence of Situational Variables. Journal of Human Kinetics, 25, 93-100. 
Lago-Peñas, C., \& Lago-Ballesteros, J. (2011). Game location and team quality effects on performance profiles in professional soccer. Journal of Systems Science and Medicine, 10(3), 465-471.

Lago-Peñas, C., Lago-Ballesteros, J., Dellal, A., \& Gómez, M. (2010). Game-related statistics that discriminated winning, drawing and losing teams from the Spanish soccer league. Journal of Systems Science and Medicine, 9(2), 288-293.

Lago-Peñas, C., Rey, E., Lago-Ballesteros, J., Casáis, L., \& Domínguez, E. (2011). The influence of a congested calendar on physical performance in elite soccer. Journal of Strength and Conditioning Research, 25(8), 2111-2117. https://doi.org/10.1519/jsc.0b013e3181eccdd2

Lames, M. (1998). Techniktraining im Tennis durch Computersimulation. En Sportspiele: animieren trainieren (In R. Andresen \& G. Hagedorn (Hrsg), pp. 181-191). Ahrensburg: Czwalina.

Lames, M., \& MacGarry, T. (2007). On the search for reliable performance indicators in game sports. International Journal of Performance Analysis in Sport, 7(1), 62-79. https://doi.org/10.1080/24748668.2007.11868388

López, R. (2007). Análisis de la táctica grupal ofensiva de los equipos participantes en el campeonato mundial de fútbol de Alemania 2006. Revista Digital-Buenos Aires, 12(114).

Losada, J. L., \& Manolov, R. (2014). The process of basic training, applied training, maintaining the performance of an observer. Quality \& Quantity. https://doi.org/10.1007/s11135-014-9989-7

MacGarry, T., Anderson, D. ., Wallace, S. ., Hughes, M. D., \& Franks, I. . (2002). Sport competition as a dynamical self-organizing system. Journal of Sports Sciences, 20, 771-781. https://doi.org/10.1080/026404102320675620

Martins. (2010). Metodologia observacional em futebol: detecção de padrões de comportamento no proceso defensivo. Universidade de Trás-os-Montes e Alto Douro, Vila Real.

Mckenzie, R., \& Cushion, C. (2012). Performance analysis in football: A critical review and implications for future research. Journal of Sports Sciences, 12, 1-38.

Perea, A. (2008). Análisis de las acciones colectivas en el fútbol de rendimiento. Universidad del País Vasco, Vitoria-Gasteiz.

Rees, G., James, N., Hughes, M., \& Taylor, J. B. (2011). The effect of match status on attacking strategies in the English Championship. En Research Methods and Performance Analysis (In M. Hughes, H. Dancs, K. Nagyváradi, T. Polgár, N. James, G. Sporis \& G. Vuckovic, pp. 172-176). Spronn: University of West Hungary.

Remmert, H. (2003). Analysis of group-tactical offensive behavior in elite basketball on the basis of a process orientated model. European Journal of Sport Science, 3(3), 1-12. https://doi.org/10.1080/17461390300073311

Sampaio, J. E., \& Leite, N. (2013). Performance indicators in game sports. En Routlege handbook of sport performance analysis (In T. MacGarry, P. O’Donoghue y J. Sampaio, pp. 115-139). London: Routledge. https://doi.org/10.4324/9780203806913.ch10

Sampaio, J. E., \& Maçãs, V. (2012). Measuring tactical behaviour in football. International Journal of Sport Medicine, 33(5), 395-401. https://doi.org/10.1055/s-0031-1301320

Suzuki, K., \& Nishijima, T. (2004). Validity of a soccer defending skill scale (SDSS) using game performances. International Journal of Sport and Health Science, 2, 34-49. https://doi.org/10.5432/ijshs.2.34

Taylor, J. B., Mellalieu, S. ., \& James, N. (2005). A comparison of individual and unit tactical behaviour and team strategy in profes- sional soccer. International Journal of Performance Analysis in Sport, 5(2), 87-101. https://doi.org/10.1080/24748668.2005.11868329

Taylor, J. B., Mellalieu, S. ., James, N., \& Shearer, D. A. (2008). The influence of match location, quality of opposition, and match status on technical performance in professional association football. Journal of Sports Sciences, 26(9), 885-895. https://doi.org/10.1080/02640410701836887 
Tenga, A., Holme, I., Ronglan, L. T., \& Bahr, R. (2010). Effect of playing tactics on goal scoring in Norwegian professional soccer. Journal of Sports Sciences, 28(3), 237-244. https://doi.org/10.1080/02640410903502774

Vogelbein, M., Noops, S., \& Hökelmann, A. (2014). Defensive transition in soccer are prompt possession regains a measure of success? A quantitative analisys of German Fußball-Bundesliga 2010/2011. Journal of Sports Sciences. https://doi.org/10.1080/02640414.2013.879671

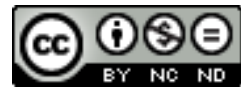

This work is licensed under a Attribution-NonCommercial-NoDerivatives 4.0 International (CC BY-NC-ND 4.0). 